\title{
EVALUATION OF INSECTICIDE ACTIVITY OF TWO AGRICULTURAL DETERGENTS AGAINST THE LONG-TAILED MEALYBUG, Pseudococcus longispinus (HEMIPTERA: PSEUDOCOCCIDAE), IN LABORATORY
}

\author{
Evaluación de la acción insecticida de dos detergentes agrícolas contra el chanchito \\ blanco de cola larga, Pseudococcus longispinus (Hemiptera: Pseudococcidae), \\ en laboratorio
}

Tomislav Curkovic*1, Gary Burett ${ }^{1}$, and Jaime E. Araya ${ }^{1}$

\begin{abstract}
A B S T R A C T
The insecticide effect of agricultural detergents SU 120 and Tecsa Fruta was evaluated on females and nymphs II of Pseudococcus longispinus (Targioni \& Tozzetti) in the laboratory. Mortality at $24 \mathrm{~h}$ was subjected to Probit analysis to obtain the $\mathrm{LC}_{50}$. For Tecsa Fruta, a volume of $9.5 \mathrm{~mL}$ solution was sprayed, while for SU 120 , volumes of 2,4 , and $8 \mathrm{~mL} 100 \mathrm{~mL}^{-1}$ solution were evaluated. Mortality was directly related to the concentration used. Nymphs II were more susceptible than females to both detergents. $\mathrm{LC}_{50}$ for Tecsa Fruta were $17.9 \mathrm{~mL} 100 \mathrm{~mL}^{-1}$

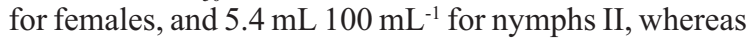
for SU 120 they were $3.1,1.6$, and $1.9 \mathrm{~mL}^{-1} 100 \mathrm{~mL}^{-1}$ on females, and $0.8,0.5$, and $0.5 \mathrm{~mL} 100 \mathrm{~mL}^{-1}$ (with 2, 4, and $8 \mathrm{~mL}$, respectively) on nymphs II. For the latter, there were no significant differences among volumes, and for females, the $\mathrm{LC}_{50}$ with 4 and $8 \mathrm{~mL}$ solution were not statistically different, although these two volumes were statistically smaller than in the treatment with $2 \mathrm{~mL}$. For the same SU 120 concentration, mortality of females increased with greater volumes sprayed. SU 120 had a significantly greater insecticide effect than Tecsa Fruta on P. longispinus nymphs II and females. Nymphs II were the most susceptible stage. Results suggest that it would be possible to reduce detergent concentration using greater spray volumen to achieve similar mortality.
\end{abstract}

Key words: agricultural detergents, bioassays, $\mathrm{LC}_{50}$, Pseudococcus longispinus, SU 120, Tecsa Fruta.

\section{R E S U M E N}

Se evaluó el efecto insecticida de los detergentes agrícolas SU 120 y Tecsa Fruta sobre hembras y ninfas II de Pseudococcus longispinus (Targioni \& Tozzetti) en laboratorio. La mortalidad a las 24 h se sometió a análisis Probit para obtener las concentraciones letales medias $\left(\mathrm{CL}_{50}\right)$. Para Tecsa Fruta se asperjó un volumen de $9,5 \mathrm{~mL}$ de solución, mientras que para $\mathrm{SU}$ 120 se evaluaron 2 , 4 y $8 \mathrm{~mL} 100 \mathrm{~mL}^{-1}$ de solución. La mortalidad fue directamente proporcional a la concentración utilizada. Las ninfas II fueron más susceptibles que las hembras a ambos detergentes. Las $\mathrm{CL}_{50}$ para Tecsa Fruta fueron 17,9 mL $100 \mathrm{~mL}^{-1}$ para hembras y $5,4 \mathrm{~mL} 100 \mathrm{~mL}^{-1}$ para ninfas II, mientras que para SU 120 fueron 3,$1 ; 1,6$ y $1,9 \mathrm{~mL} 100 \mathrm{~mL}^{-1}$ en

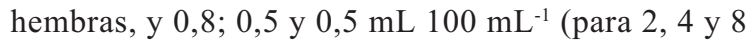
$\mathrm{mL}$, respectivamente) en ninfas II. Para éstas no hubo diferencias significativas entre volúmenes, y para hembras las $\mathrm{CL}_{50}$ con 4 y $8 \mathrm{~mL}$ de solución no fueron estadísticamente diferentes entre sí, aunque estos dos volúmenes fueron estadísticamente inferiores al tratamiento con $2 \mathrm{~mL}$. Para una misma concentración de SU 120, la mortalidad de hembras aumentó con volúmenes mayores de aspersión. SU 120 presentó un efecto insecticida significativamente mayor que Tecsa Fruta en ninfas II y hembras de P. longispinus. Las ninfas II fueron el estadío más susceptible. Los resultados sugieren que sería posible reducir la concentración de detergente con volúmenes mayores de aspersión para lograr mortalidades similares.

Palabras clave: bioensayos, $\mathrm{CL}_{50}$, detergentes agrícolas, Pseudococcus longispinus, SU 120, Tecsa Fruta.

\footnotetext{
${ }^{1}$ Universidad de Chile, Facultad de Ciencias Agronómicas, Casilla 1004, Santiago, Chile. E-mail: tcurkovi@uchile.cl*Author for correspondence. Received: 10 de noviembre de 2006. Accepted: 12 de enero de 2007.
} 


\section{INTRODUCTION}

Control of mealybugs (Hemiptera: Pseudococcidae) is complex, due to their particular biology, morphology and behavior. These insects are located in sites that are protected and difficult to reach with sprays, they infest foliage and fruits throughout the season, and have a highly hydrophobic and difficult to wet cuticle. Direct damage is caused partially by its phloem feeding habit and the production of abundant honeydew, a substrate on which saprophytic fungi grow (Artigas, 1994; Ripa and Rodríguez, 1999). Crops are also affected by their capacity of vectoring pathogenic agents (Golino et al., 2002), and particularly by their quarantine situation (Aguirre et al., 2003).

Their management is also difficult because there are neither efficient monitoring techniques nor many efficacious insecticides that at the same time are registered, or do not cause plant toxicity in orchards (Ripa and Rojas, 1990; Prado, 1991). Agricultural detergents are a low cost alternative to manage pests with low environmental impact, and they lack residual effect.

The objective of this research was to determine the mean lethal concentration ( $\mathrm{LC}_{50}$ ) of two agricultural detergents on second stage nymphs and adult females of the long-tailed grape mealybug, under laboratory conditions.

\section{MATERIALS AND METHODS}

Assays were conducted in the Laboratory of Toxicology, Departamento de Sanidad Vegetal, Facultad de Ciencias Agronómicas, Universidad de Chile, Santiago, Chile, from December 2003 through March 2004. The products evaluated were: detergent $\mathrm{A}$, a non-ionic liquid detergent with $31 \%$ fatty acids (maleates, palmitates and glycids (Tecsa Fruta, Protecsa S.A., Santiago, Chile), and detergent $\mathrm{B}$, a liquid neutral detergent with 14.9 to $17.8 \%$ anionic tensioactives (sulfonates and lauryl ether sulfonates) (SU 120, Johnson \& Diversey, Santiago, Chile).

The mealybugs used in the study came from a colony maintained for a generation on potato (Solanum tuberosum L.) sprouts kept in the dark. The original material was obtained from Nerium oleander
L. sprouts collected in the Las Condes Commune ( $33^{\circ} 24^{\prime} \mathrm{S}$ lat, $70^{\circ} 35^{\prime} \mathrm{W}$ long), and from aggregation traps (corrugated cardboard paper bands set around fruit tree trunks in the communes of La Pin-

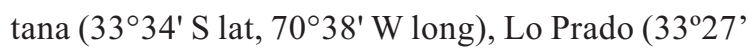

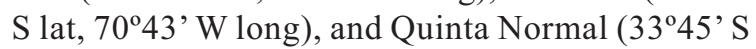
lat., $70^{\circ} 70^{\prime} \mathrm{W}$ long), in Santiago, Chile, all sites untreated previously with insecticides.

About 20 individuals of each stage (females and nymphs, separately) were set per Petri dish, and four dishes (replicates) were sprayed per treatment (concentration x volume) in a Potter tower. Concentrations and solution volumes ( $\mathrm{mL}$ detergent $100 \mathrm{~mL}^{-1}$ solution) were defined previously to obtaining a wide range of mortality levels ( 80 to $20 \%$ ), to perform Probit analyses to determine $\mathrm{LC}_{50}$ (Rustom et al., 1989). At least four concentrations were evaluated for each combination of the stage of development and spray volume. Concentration ranges were determined in preliminary experiments, and were different because of the different levels of susceptibility of each developmental stage. Volumes used were 9.5 and $4 \mathrm{~mL}$ per dish for detergent $\mathrm{A}$ and $\mathrm{B}$, respectively. For detergent $\mathrm{B}, 2$ and $8 \mathrm{~mL}$ volumes per dish were also evaluated to measure the effect of coverage on mortality, because better results were obtained with this product in previous tests. The control treatments had water in the same volumes as used with detergents.

The liquid accumulated in the dishes after each application was removed immediately by using absorbent paper. The dishes were then let to dry $10 \mathrm{~min}$ at room temperature, and the individuals treated were placed on other dishes with washed leaves (with no previous treatment of pesticides) of Vitis vinifera $\mathrm{L}$. The leaves were cleaned to eliminate natural enemies or other pseudococcids which could affect results; dishes were covered with polypropylene film to prevent the individuals from escaping, and were taken to a rearing chamber at $25.5 \pm 1{ }^{\circ} \mathrm{C}, 40 \pm 1 \%$ $\mathrm{RH}$, and 16:8 h (light:dark) photoperiod.

Mortality was evaluated $24 \mathrm{~h}$ after treatment, as well as in the control. To verify mortality or survival, a fine hair brush was used to touch the body of the insects, in order to induce and detect movements. Individuals were considered dead when presenting a darkened body and absence of leg movements after stimulus. 
Mortality at $24 \mathrm{~h}$ was subjected to Probit analysis using the Minitab (2000) software, which estimates the $\mathrm{LC}_{50}[\mathrm{~mL}$ commercial product (c.p.) $/ 100 \mathrm{~mL}$ solution], confidence interval, chi-square (a measure of fitness adjustment), its probability, and a graph with the adjusted linear regression. Four replicates were eliminated (of a total of 124) when necessary to improve goodness of fit (A. Rustom, statistician, University of Chile, personal communication, 2005). To determine statistical differences between stages, products, and volumes for SU 120 , treatments were considered to be different when their results did not overlap.

\section{RESULTS}

Detergent A. The greatest concentration used on both stages was $30 \mathrm{~mL}$ c.p. $100 \mathrm{~mL}^{-1}$ solution, at which $85 \%$ mortality was obtained on adult females, and $98.79 \%$ on second stage nymphs (Table 1 ). The smallest concentrations for adult females and second stage nymphs were 10 and $2.5 \mathrm{~mL}$ c.p. $100 \mathrm{~mL}^{-1}$ solution, and caused mortalities of 13.75 and $21.51 \%$, respectively. There was no mortality in the control, and consequently this parameter did not have to be corrected (Busvine, 1980).

The effect of this detergent was significantly greater on second stage nymphs than on adult females

Table 1. Mortality (\%) of Pseudococcus longispinus adult females and second stage nymphs $24 \mathrm{~h}$ after spraying with several concentrations ( $v / v)$ of Tecsa Fruta.

Cuadro 1. Mortalidad (\%) de hembras adultas y ninfas de segundo estado de Pseudococcus longispinus 24 h después de la aspersión con varias concentraciones (v/v) de Tecsa Fruta.

\begin{tabular}{lrrr}
\hline $\begin{array}{l}\text { Concentrations } \\
\left(\mathbf{m L} \mathbf{1 0 0} \mathbf{~ m L}^{-1} \text { solution) }\right.\end{array}$ & Alive & Dead & $\begin{array}{c}\text { Mortality } \\
\mathbf{( \% )}\end{array}$ \\
\hline Adult females & & & \\
30.0 & 12 & 68 & 85.00 \\
20.0 & 31 & 48 & 60.75 \\
15.0 & 55 & 26 & 32.09 \\
10.0 & 69 & 11 & 13.75 \\
0.0 & 80 & 0 & 0.00 \\
Second stage nymphs & & & \\
30.0 & 1 & 82 & 98.79 \\
7.5 & 26 & 56 & 68.29 \\
5.0 & 52 & 32 & 38.09 \\
2.5 & 62 & 17 & 21.51 \\
0.0 & 80 & 0 & 0.00 \\
\hline
\end{tabular}

(Table 2). The high probability values indicate a high goodness of fit for the method used (Rustom et al., 1989). The regressions of concentration log of detergent A versus mortality (Probit of percentage) of adult females and second stage nymphs are presented in Figures 1 and 2, respectively. All the figures presented are probability plot for dead individuals. Normal distribution -mL estimates95.0\% Confidence interval.

Table 2. Confidence intervals (CI) of the $\mathrm{LC}_{50}$, chisquare ( $\left(^{2}\right)$, and probability (P) for Pseudococcus longispinus adult females and second stage nymphs treated with Tecsa Fruta.

Cuadro 2. Intervalos de confianza (CI) de la $\mathrm{CL}_{50}$, chicuadrado $\left(\chi^{2}\right)$ y probabilidad (P) para hembras adultas y ninfas de segundo estadío de Pseudococcus longispinus tratadas con Tecsa Fruta.

\begin{tabular}{lccc}
\hline Stages & CI & $\boldsymbol{\chi}^{2}$ & P \\
\hline $\begin{array}{l}\text { Adult females } \\
\text { Second stage }\end{array}$ & $17.9226 \pm 1.4887 \mathrm{a}$ & 0.890 & 0.641 \\
nymphs & $5.4066 \pm 0.7878 \mathrm{~b}$ & 3.635 & 0.162 \\
\hline
\end{tabular}

Means with different letters are significantly different $(\mathrm{P} \leq 0.05)$.

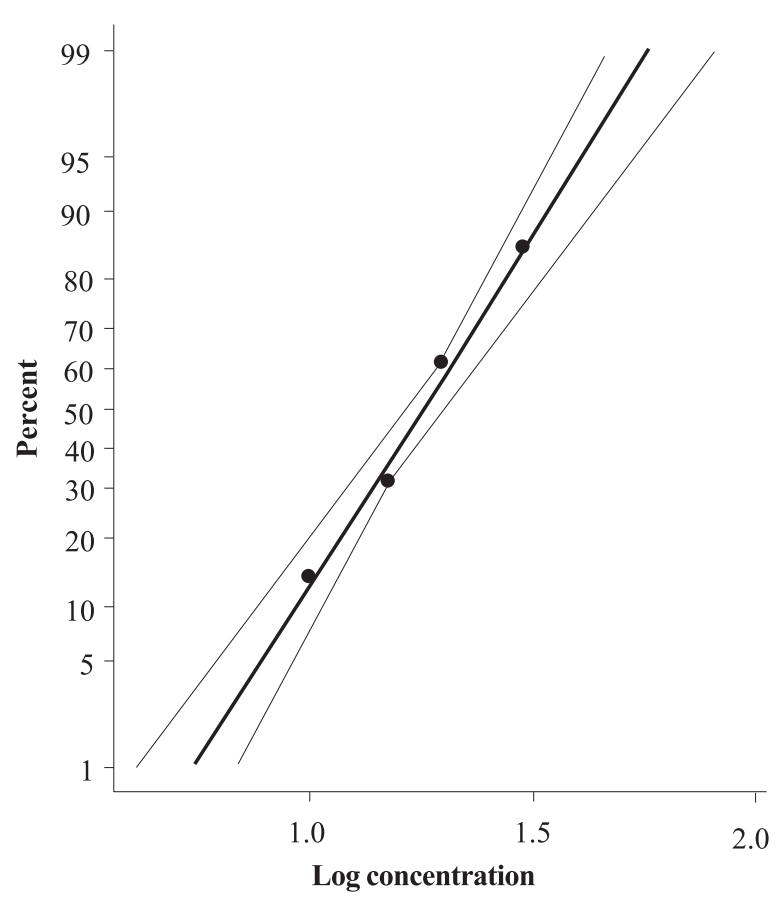

Figure 1. Probit mortality of adult females of Pseudococcus longispinus versus concentration (log) of Tecsa Fruta.

Figura 1. Mortalidad probit de hembras adultas de Pseudococcus longispinus versus la concentración (log) de Tecsa Fruta. 


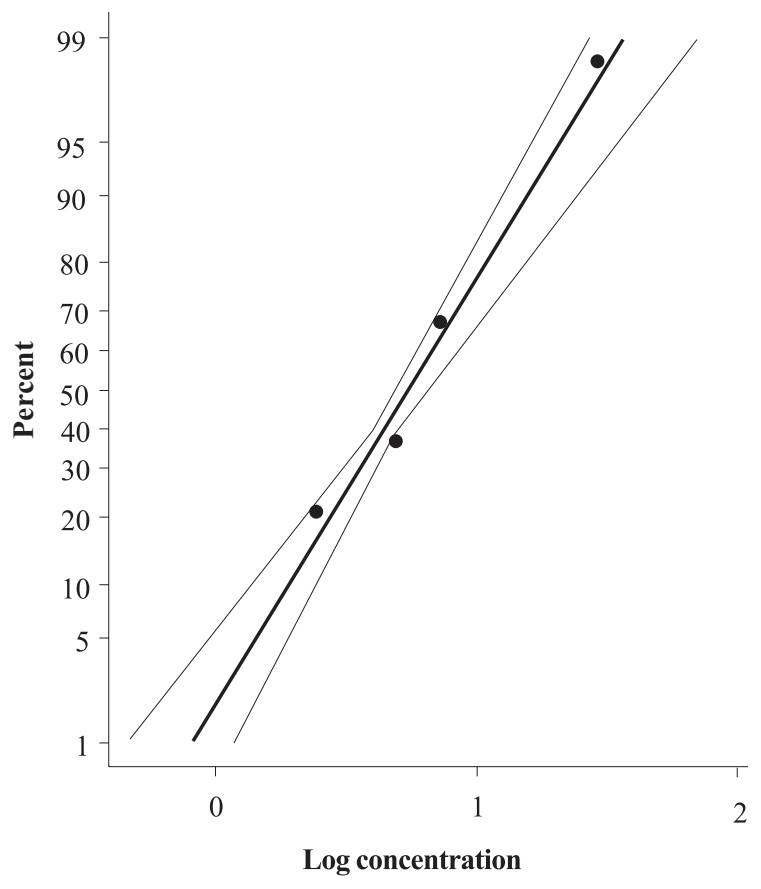

Figure 2. Probit mortality of second stage nymphs of Pseudococcus longispinus versus concentration (log) of Tecsa Fruta.

Figura 2. Mortalidad probit de ninfas de segundo estado de Pseudococcus longispinus versus la concentración (log) de Tecsa Fruta.
Detergent B. Concentrations used and mortality percentages at $24 \mathrm{~h}$ for adult females treated with 2,4 , and $8 \mathrm{~mL}$ solution are presented in Table 3. Mortality caused with water (control treatment) for the three volumes evaluated was lower than $5 \%$, from which it was not necessary to correct mortality of treatments (Busvine, 1980). In treatments with concentrations of 5 and $1.25 \mathrm{~mL}$ c.p. $100 \mathrm{~mL}^{-1}$ solution and a $2 \mathrm{~mL}$ volume of sprayed solution, a replicate was eliminated to improve goodness of fit. Figures 3, 4, and 5 present regressions of log concentration for SU 120 at volumes of 2, 4, and $8 \mathrm{~mL}$, respectively, versus adult females probit mortality.

Mortality results with the concentrations of detergent $B$ used on second stage nymphs are observed in Table 4. The greatest concentration of $5 \mathrm{~mL}$ c.p. $100 \mathrm{~mL}^{-1}$ solution for the three volumes evaluated caused $>80 \%$ mortality; the lowest concentration ( $0.16 \mathrm{~mL}$ c.p. $100 \mathrm{~mL}^{-1}$ solution) for the three volumes obtained mortality below $24 \%$.

With the $4 \mathrm{~mL}$ application volume, a replicate with the $0.16 \%$ concentration was also eliminated, as with the $8 \mathrm{~mL}$ volume in the treatment with the $1.25 \%$ concentration. Figures 6,7 , and 8 present the regressions of the logarithm of concentration of detergent $\mathrm{B}$ versus probit mortality of second stage nymphs.

Table 3. Mortality (\%) of Pseudococcus longispinus adult females treated with several concentrations (v/v) and volumes of 2,4 , and $8 \mathrm{~mL}$ solution of $\mathrm{SU} 120,24 \mathrm{~h}$ after spraying.

Cuadro 3. Mortalidad (\%) de hembras adultas de Pseudococcus longispinus tratadas con varias concentraciones (v/v) y volúmenes de 2,4 y $8 \mathrm{~mL}$ de solución de $\mathrm{SU}$ 120, 24 h después de la aspersión.

\begin{tabular}{lrcc}
\hline Concentrations (mL c.p. $\mathbf{1 0 0} \mathbf{~ m L}^{-\mathbf{1}}$ solution) & Alive & Dead & Mortality (\%) \\
\hline $2 \mathrm{~mL}$ application volume & 7 & & \\
10.00 & 22 & 33 & 91.25 \\
5.00 & 46 & 14 & 63.93 \\
1.25 & 79 & 1 & 23.33 \\
0.63 & 80 & 0 & 1.25 \\
0.00 & & & 0.00 \\
$4 \mathrm{~mL}$ application volume & 4 & 76 & 95.00 \\
10.00 & 22 & 58 & 72.50 \\
2.50 & 46 & 34 & 42.50 \\
1.25 & 68 & 12 & 15.00 \\
0.63 & 79 & 1 & 1.25 \\
0.00 & & & \\
$8 \mathrm{~mL}$ application volume & 5 & 75 & 93.75 \\
5.00 & 22 & 58 & 72.50 \\
2.50 & 53 & 27 & 33.75 \\
1.50 & 78 & 2 & 2.50 \\
0.63 & 80 & 0 & 0.00 \\
\hline .00 & & & \\
\hline
\end{tabular}

c.p.: commercial product. 


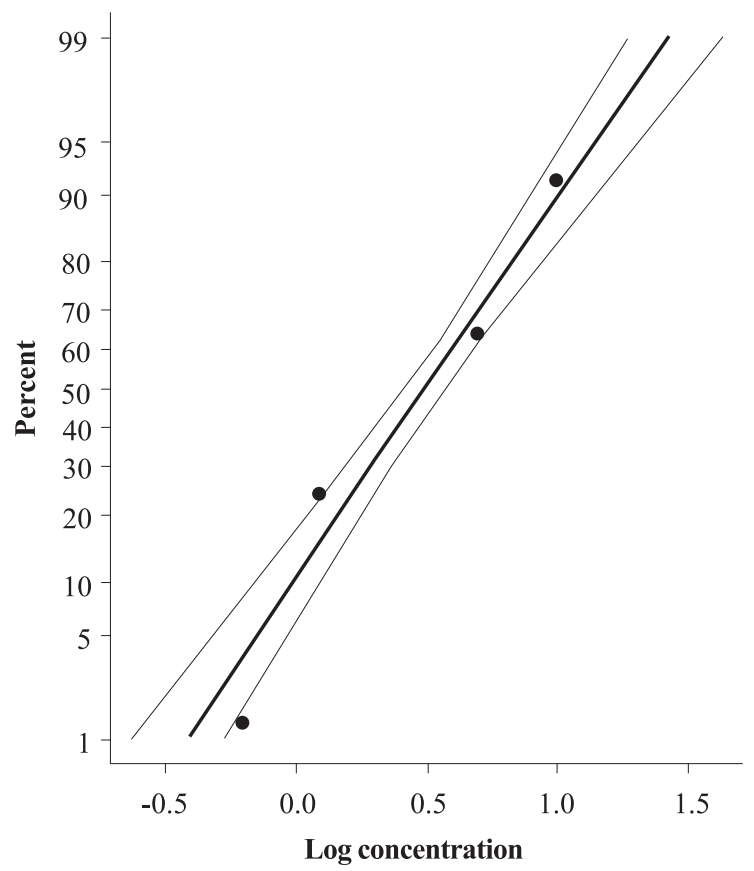

Figure 3. Probit mortality of adult females of Pseudococcus longispinus versus concentration (log) of SU 120 applied at $2 \mathrm{~mL}$ solution.

Figura 3. Mortalidad probit de hembras adultas de Pseudococcus longispinus versus la concentración (log) con un volumen de $2 \mathrm{~mL}$ de solución de SU 120.

When comparing $\mathrm{LC}_{50}$ for adult females and second stage nymphs treated with the three solution volumes, it is observed that within the same volume, significantly smaller concentrations of the detergent are required $\left(\mathrm{LC}_{50}\right.$ are not overlapping) to eliminate $50 \%$ of nymphs (Table 5 ).

There were no differences in mortality of second stage nymphs among the different solution volumes used, while adult females mortality varied between application volumes, with significant differences between $2 \mathrm{~mL}$ and the other volumes evaluated (4 and $8 \mathrm{~mL}$ ), which were significantly more active than the same volumes on nymphs. The high probability values indicate a significant goodness of fit for the method used (Rustom et al., 1989).

\section{Comparison between detergent $A$ and detergent} B. Activity of both detergents on P. longispinus was

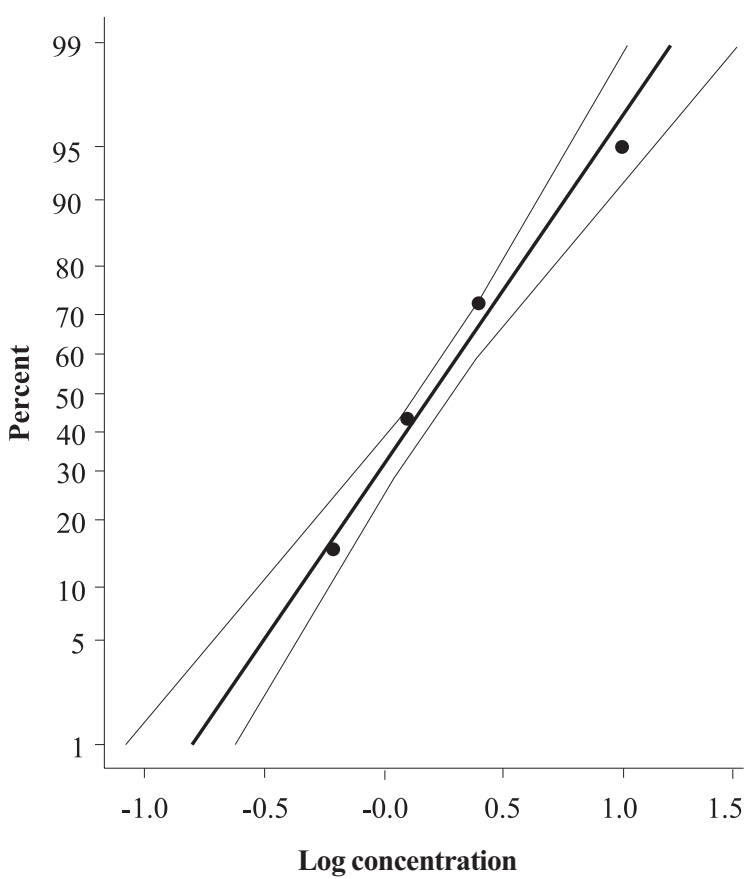

Figure 4. Probit mortality of adult females of Pseudococcus longispinus versus concentration (log) of SU 120 applied at $4 \mathrm{~mL}$ solution.

Figura 4. Mortalidad probit de hembras adultas de Pseudococcus longispinus versus la concentración (log) en un volumen de $4 \mathrm{~mL}$ de solución de $\mathrm{SU}$ 120.

compared based on the $\mathrm{LC}_{50}$ for both stages (Table $6)$. At the three volumes and for both stages, detergent $\mathrm{B}$ was more effective (lower $\mathrm{LC}_{50}$ ) than detergent $A$ at $9.5 \mathrm{~mL}$, since smaller concentrations of the first were required to kill $50 \%$ of individuals treated.

\section{DISCUSSION}

The agricultural detergents A and B were compared only as commercial products because they have different compositions. SU 120 was significantly more active than Tecsa Fruta to control both stages of $P$. longispinus. Previous research (Curkovic and Araya, 2004) presented significant differences between Quix (a product similar to SU 120) and Nobla, other household detergents. Recently, Curkovic et al. (2006) compared the insecticide/ acaricide activity of both detergents (SU 120 and 


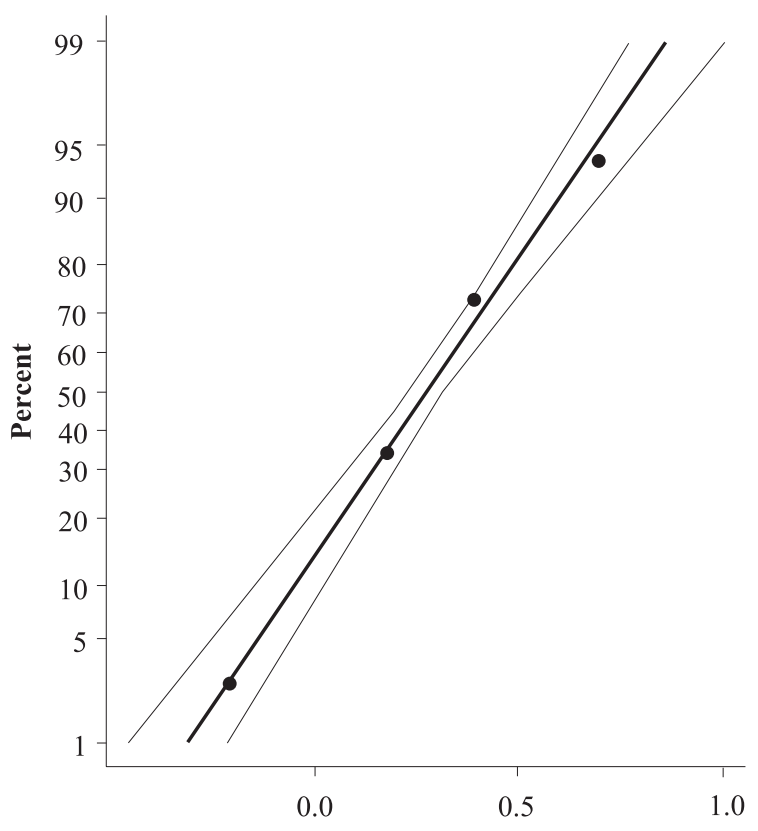

Log concentration

Figure 5. Probit mortality of adult females of Pseudococcus longispinus versus concentration (log) of SU 120 applied at $8 \mathrm{~mL}$ solution.

Figura 5. Mortalidad probit de hembras adultas de Pseudococcus longispinus versus la concentración (log) en un volumen de $8 \mathrm{~mL}$ de solución de $\mathrm{SU}$ 120.

Tecsa Fruta) against Myzus persicae (Sulzer) (Hemiptera: Aphididae) and Tetranychus urticae Koch (Acarina: Tetranychidae), and concluded that SU 120 also had a higher pesticide action on both species. As well, the greater content of active ingredients in the formulation of Tecsa Fruta (31\%), compared with a maximum $17.8 \%$ in SU 120 , suggests that the activity of different detergents depends both on the active ingredients and their corresponding concentrations.

It is important to note that some $\mathrm{LC}_{50}$ were too high to be of practical use in the field. For example, $510 \mathrm{~L}$ of Tecsa Fruta in $3000 \mathrm{~L}$ water $\mathrm{ha}^{-1}$ would be required to control only $50 \%$ of females (Table 2), with a cost that is not competitive with treatments of conventional insecticides. As well, this concentration represents a serious risk of toxicity to crops.

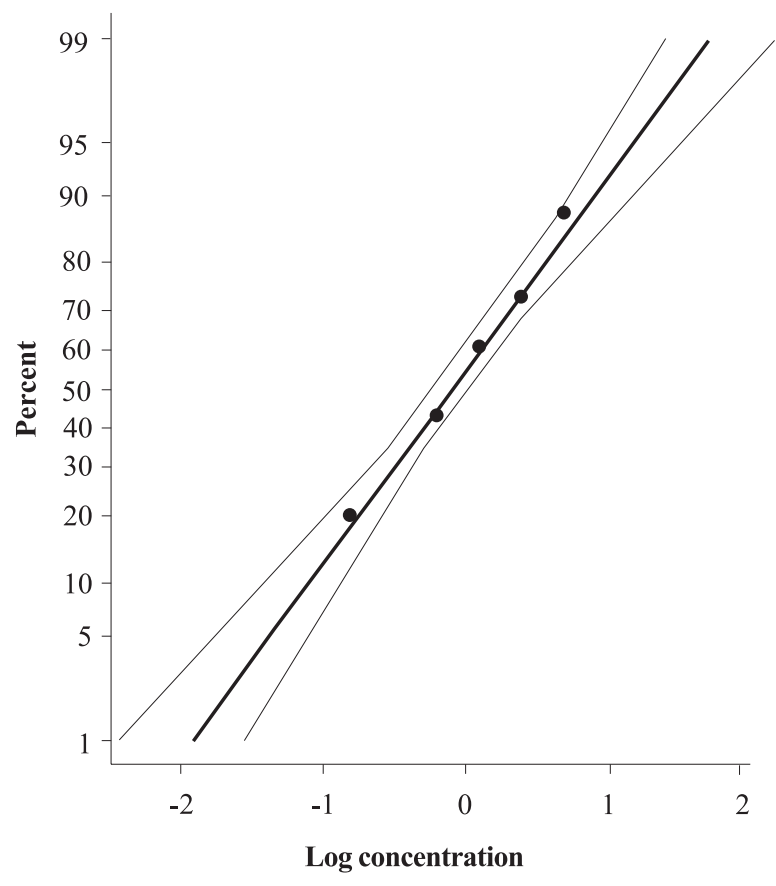

Figure 6. Probit mortality of second stage nymphs of Pseudococcus longispinus versus concentration (log) of SU 120 applied at $2 \mathrm{~mL}$ solution.

Figura 6. Mortalidad probit de ninfas de segundo estado de Pseudococcus longispinus versus la concentración (log) en un volumen de aplicación de $\mathbf{2} \mathrm{mL}$ de solución de $\mathrm{SU} \mathbf{1 2 0}$.

The results of this study indicated that, for a given detergent, the use of greater volumes of solution and/or concentrations produces higher mortality, which coincides with several studies on the effect of detergents on diverse pests (Ripa et al., 2006; Curkovic et al., 2006). When using low volumes and/or concentrations, some individuals survived, but had signs of wax removed, giving them a brownish appearance. This suggests that mortality was due mainly to dehydration as a consequence of removal of wax and other epicuticular components. Individuals treated also had uncoordinated movements and/or absence of leg movements when placed upside down, and were unable to stand up and walk. At high concentrations, mealybugs were immobilized after the spraying, adhering to the leaf surface by the waxes removed from their bodies by the detergent, which had accumulated under them. 
Table 4. Mortality (\%) of Pseudococcus longispinus second stage nymphs treated with several concentrations (v/v) and volumes of 2,4 , and $8 \mathrm{~mL}^{-1}$ solution of $\mathrm{SU} 120,24 \mathrm{~h}$ after spraying.

Cuadro 4. Mortalidad (\%) de ninfas de segundo estado de Pseudococcus longispinus tratadas con varias concentraciones (v/v) y volúmenes de 2,4 y $8 \mathrm{~mL}^{-1}$ de solución de $\mathrm{SU} 120,24 \mathrm{~h}$ después de la aspersión.

\begin{tabular}{cccc}
\hline Dosages (mL c.p. $\mathbf{1 0 0} \mathbf{~ m L}^{-1}$ solution) & Alive & Dead & Mortality (\%) \\
\hline 2 mL application volume & & & \\
5.00 & 10 & 70 & 87.50 \\
2.50 & 22 & 58 & 72.50 \\
1.25 & 32 & 49 & 60.49 \\
0.63 & 46 & 34 & 42.50 \\
0.16 & 64 & 16 & 20.00 \\
0.00 & 77 & 3 & 3.75 \\
4 mL application volume & & & \\
5.00 & 2 & 85 & 97.70 \\
2.50 & 10 & 74 & 88.09 \\
0.63 & 45 & 37 & 45.12 \\
0.16 & 46 & 14 & 23.33 \\
0.00 & 77 & 3 & 3.75 \\
5 mL application volume & & & \\
5.00 & 1 & 78 & 98.73 \\
1.25 & 14 & 47 & 77.04 \\
0.32 & 56 & 26 & 31.70 \\
0.16 & 65 & 15 & 18.75 \\
\hline
\end{tabular}

c.p.: commercial product

Table 5. Confidence intervals (CI) of $\mathrm{LC}_{50}$, chi-square $\left(\chi^{2}\right)$, and probability (P) of SU 120 on Pseudococcus longispinus adult females and second stage nymphs treated with volumes of 2,4 , and $8 \mathrm{~mL}$ solution.

Cuadro 5. Intervalos de confianza (CI) de la $C_{50}$, chi-cuadrado $\left(\chi^{2}\right)$ y probabilidad (P) de $S U 120$ para hembras adultas y ninfas de segundo estadío de Pseudococcus longispinus tratadas con volúmenes de 2,4 y $8 \mathrm{~mL}$ de solución.

\begin{tabular}{lcccc}
\hline Stages & Application volume (mL) & CI & $\boldsymbol{\chi}^{\mathbf{2}}$ & P \\
\hline Adult females & 2 & $3.1297 \pm 0.608 \mathrm{a}$ & 5.192 & 0.075 \\
Adult females & 4 & $1.5635 \pm 0.279 \mathrm{~b}$ & 2.125 & 0.345 \\
Adult females & 8 & $1.8819 \pm 0.204 \mathrm{~b}$ & 2.125 & 0.345 \\
Second stage nymphs & 2 & $0.7798 \pm 0.209 \mathrm{c}$ & 0.850 & 0.837 \\
Second stage nymphs & 4 & $0.5363 \pm 0.139 \mathrm{c}$ & 4.707 & 0.095 \\
Second stage nymphs & 8 & $0.4951 \pm 0.116 \mathrm{c}$ & 1.296 & 0.523 \\
\hline
\end{tabular}

Means with different letters are significantly different $(\mathrm{P} \leq 0.05)$.

Table 6. $\mathrm{LC}_{50}$ of SU 120 and Tecsa Fruta for Pseudococcus longispinus adult females and second stage nymphs. Cuadro 6. $\mathrm{LC}_{50}$ de $\mathrm{SU} 120$ y Tecsa Fruta para hembras adultas y ninfas de segundo estadío de Pseudococcus longispinus.

\begin{tabular}{lcc}
\hline Products and volume & LC $_{\mathbf{5 0}}$ adult females & LC $_{\mathbf{5 0}}$ second stage nymphs \\
\hline Tecsa Fruta, $9.5 \mathrm{~mL}$ & $17.9226 \mathrm{a}$ & $5.4063 \mathrm{a}$ \\
SU 120, $2 \mathrm{~mL}$ & $3.1297 \mathrm{~b}$ & $0.7798 \mathrm{~b}$ \\
SU 120, 4 mL & $1.5635 \mathrm{c}$ & $0.5363 \mathrm{~b}$ \\
SU $120,8 \mathrm{~mL}$ & $1.8819 \mathrm{c}$ & $0.4951 \mathrm{~b}$ \\
\hline
\end{tabular}

Means in a column with different letters are significantly different $(\mathrm{P} \leq 0.05)$. 


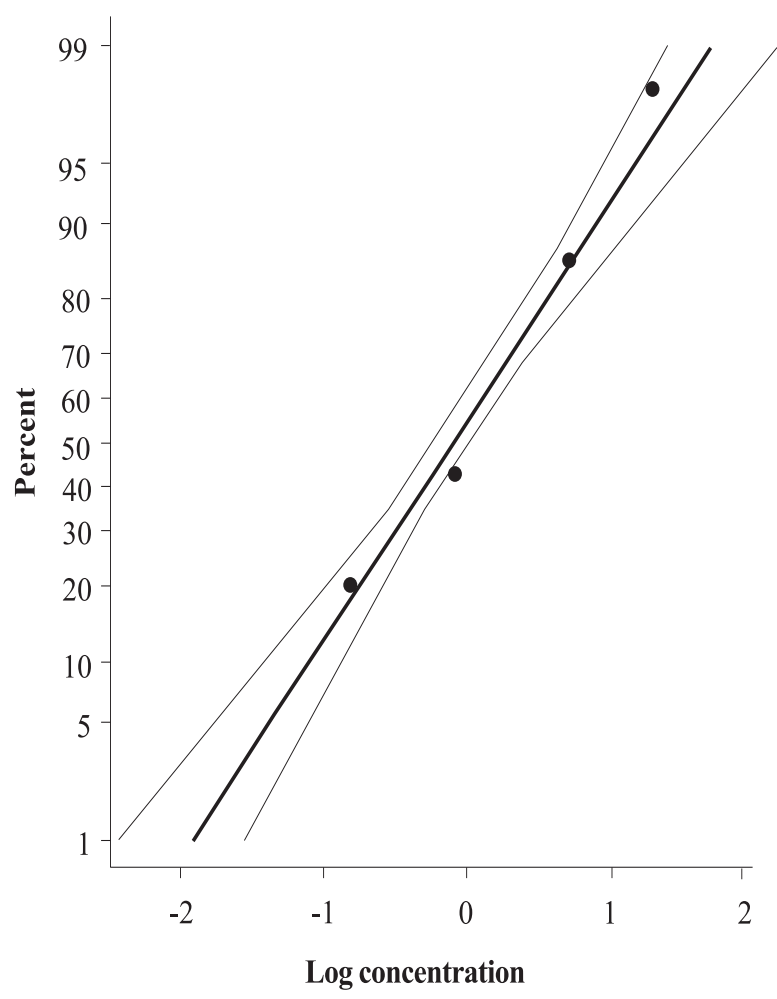

Figure 7. Probit mortality of second stage nymphs of Pseudococcus longispinus versus concentration (log) of SU 120 applied at $4 \mathrm{~mL}$ solution.

Figura 7. Mortalidad probit de ninfas de segundo estado de Pseudococcus longispinus versus la concentración $(\log )$ en un volumen de aplicación de $4 \mathrm{~mL}$ de solución de SU 120.

Both detergents affected juveniles of pseudococcids at concentrations smaller than for adults, as has been observed with other hemipterans (Prado et al., 2003; Curkovic et al., 2006). This is probably related to the smaller size of nymphs and their having less amount surface waxes, which makes them more susceptible than adults to dehydration. As well, the decrease of superficial tension caused by detergent solutions may have contributed to total mortality by the drowning of individuals, another mode of action attributed to detergents used against arthropods (Curkovic and Araya, 2004). For second stage $P$. longispinus nymphs there were no significant differences for $\mathrm{LC}_{50}$ with the 2,4 , and $8 \mathrm{~mL}$ volumes applied of SU 120 , while for adult females the treatments with 8 and $4 \mathrm{~mL}$, although without differences among them, both had $\mathrm{LC}_{50}$ significantly smaller than $2 \mathrm{~mL}$ vol-

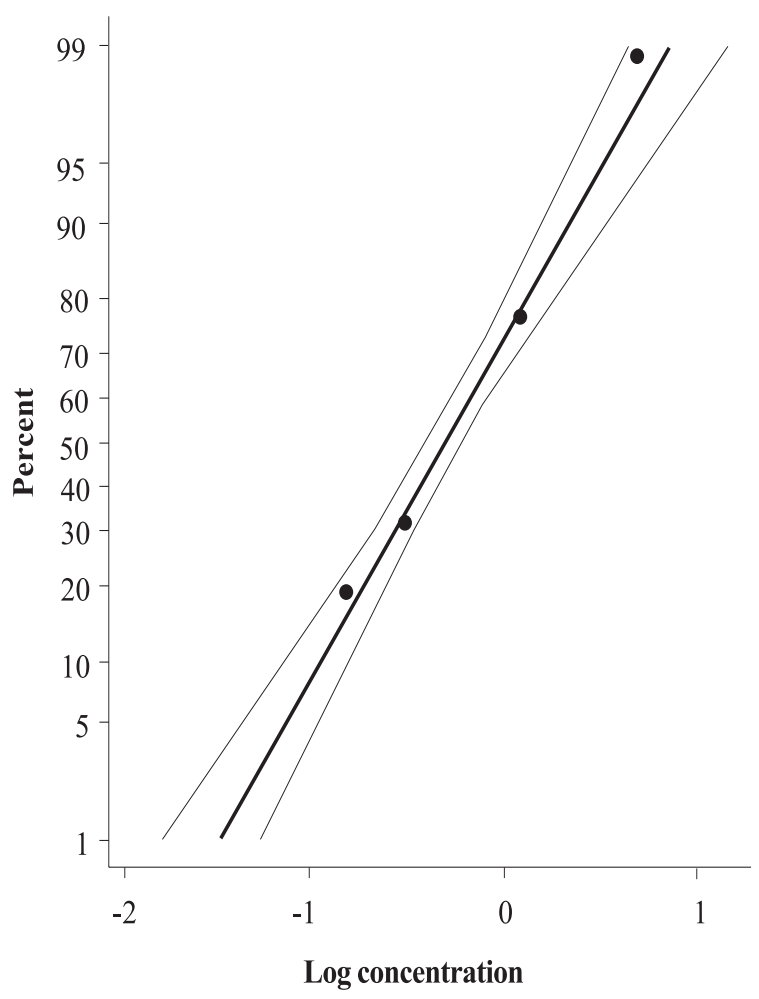

Figure 8. Probit mortality of second stage nymphs of Pseudococcus longispinus versus concentration (log) of SU 120 applied at $8 \mathrm{~mL}$ solution.

Figura 8. Mortalidad probit de ninfas de segundo estado de Pseudococcus longispinus versus la concentración (log) en un volumen de aplicación de $8 \mathrm{~mL}$ de solución de SU 120.

ume treatment. The results suggest that greater spraying volumes in the field would give better control levels of these insects. With Tecsa Fruta, $9.5 \mathrm{~mL}$ was used for both evaluated stages, the greatest volume possible to spray in the Potter tower, with a $\mathrm{LC}_{50}$ significantly larger when compared with those of SU 120 for both stages and at three volumes. On the other side, it is necessary to evaluate these detergents in the field, in order to study some spray factors, such as droplet size and mortality by washing and removal of individuals from the plant (Curkovic and Araya, 2004), which were not evaluated in this study.

To control $>90 \%$ of individuals sprayed would require concentrations greater than $2 \%$ of both detergents, which would prevent using them on susceptible plants presenting symptoms of toxicity at these 
concentrations). However, the use of lower concentrations that do not affect crops may be an alternative in an integrated management scheme including repeated use of detergents.

\section{CONCLUSIONS}

- Mortality caused with both detergents was directly proportional to the concentration used.

- For the same concentration of SU 120, mor- tality of females increased when using greater spraying volumes.

- Second stage nymphs were more susceptible than adult females to the action of both detergents.

- Results suggest it may be possible to reduce concentration of the detergent when using greater spraying volumes to obtain similar mortality.

\section{LITERATURE CITED}

Aguirre, C., R. Pérez, y P. Hinrichsen. 2003. Detección de dos nuevas especies de chanchito blanco (Hemiptera: Pseudococcidae) basado en la amplificación por PCR de genes ribosomales. p. 12. Resúmenes XXV Congreso Nacional de Entomología. 26-28 nov. 2033.Universidad de Talca, Talca, Chile. Disponible en http://entomologia.utalca.cl/congreso/ resumen.htm Leído el 18 de abril de 2005.

Artigas, J.N. 1994. Entomología económica: insectos de interés agrícola, forestal, médico y veterinario (nativos, introducidos y susceptibles de ser introducidos). Vol. 1. p. 787-809. Ed. Univ. Concepción, Concepción, Chile.

Busvine, J. 1980. Recommended methods for measurement of pest resistance to pesticides. $132 \mathrm{p}$. FAO, Rome, Italy.

Curkovic, T., and J.E. Araya. 2004. Acaricidal action of two detergents against Panonychus ulmi (Koch) and Panonychus citri (McGregor) (Acarina: Tetranychidae) in the laboratory. Crop Prot. 23:731-733.

Curkovic, T., J.E. Araya, A. Medina, and C. Canales. 2006. Evaluation of two agriculture detergents as control alternatives for the green peach aphid and two-spotted spider mite, two pests affecting peach orchards in Chile. Acta Hort. (ISHS) 713:405-408.

Golino, D., S. Sim, R. Gill, and A. Rowhani. 2002. California mealybugs can spread grapevine leafroll disease. Calif. Agric. 56(6):196-201.

Minitab. 2000. User's guide to statistics. Minitab Software versión 13.32. Minitab Inc., State College, Pennsylvania, USA.
Prado, E. 1991. Principales artrópodos y sus enemigos naturales asociados a cultivos en Chile. Boletín Técnico $\mathrm{N}^{\mathrm{o}}$ 169. 207 p. Instituto de Investigaciones Agropecuarias, Centro Regional de Investigación La Platina, Santiago, Chile.

Prado, E., P. Larraín, H. Vargas, y D. Bobadilla. 2003. Plagas del olivo, sus enemigos naturales y manejo. Colección Libros INIA $\mathrm{N}^{\circ} 8.74$ p. Instituto de Investigaciones Agropecuarias, Santiago, Chile.

Ripa, R., y F. Rodríguez. 1999. Plagas de cítricos, sus enemigos naturales y manejo. Colección Libros INIA $\mathrm{N}^{\circ} 3.151 \mathrm{p}$. Instituto de Investigaciones Agropecuarias, Santiago, Chile.

Ripa, R., y S. Rojas. 1990. Manejo y control biológico del chanchito blanco de la vid. Revista Frutícola 11(3):82-87.

Ripa, R., F. Rodríguez, P. Carral, y R. Luck. 2006. Evaluación de un detergente en base a benceno sulfonato de sodio para el control de la mosquita blanca Aleurothrixus floccosus (Maskell) (Hemiptera: Aleyrodidae) y de la arañita roja Panonychus citri (McGregor) (Acarina: Tetranychidae) en naranjos y mandarinos. Agric. Téc. (Chile) 66:115-123.

Rustom, A., B. Latorre, y M. Lolas. 1989. Método para la correcta comparación de la efectividad de nuevos fungicidas. p. 149-164. In Latorre, B. (ed.) Fungicidas y nematicidas. Avances y aplicaciones. Colección en Agricultura. Universidad Católica, Facultad de Agronomía, Santiago, Chile. 